\title{
THE IMPACT OF THE METEOROLOGICAL FACTORS ON THE CALCULATION OF CROPS WATER CONSUMPTION AND VERTICAL MOISTURE EXCHANGE IN SOIL
}

\author{
Yury A. Mazhayskiy ${ }^{1}$, Krystyna Bryś $^{2 \bowtie}$, Tatiana M. Guseva ${ }^{3}$, Artem A. Pavlov ${ }^{4}$ \\ ${ }^{1}$ Meshcherskiy Branch of the VNIIGiM, Meshcherskaya st. 1a, 390-021 Ryazan, Russia \\ 2 Institute of Environmental Protection and Development, Wrocław University of Environmental and Life Sciences, Plac Grunwaldzki \\ 24, 50-363 Wrocław, Poland \\ ${ }^{3}$ FSBEI HE RyazSMU named after academician I.P. Pavlov,Visokovoltnaya st. 9, 390-026 Ryazan, Russia \\ ${ }^{4}$ RSATU named after P.A. Kostychev, Kostycheva st. 1, 390-044 Ryazan, Russia
}

\begin{abstract}
Aim of the study

The aim of the work was to develop methods for calculating water consumption of plants and vertical moisture exchange, focusing on the impact of meteorological factors upon the agricultural conditions of reclaimed soils.

Material and methods

The methods of Shebeko, Rogotskiy and Pylenok, which are commonly used in Russia, were assumed as the basis of the study. The research was carried out on an ecological landfill created in the Oka river basin near Riazań (central part of the Russian Plain). The empirical data of agro-climatologic, radiation, lysimetric and soil moisture measurements in the period from the beginning of May to the end of September during the years 1981-2018 were taken into account in the conducted analyses. Processing of research materials was carried out using such methods as analysis of variance, calculation of statistical characteristics of the sample, linear correlation. The analysis of the influence of meteorological factors on the water balance of soil with three agricultural crops: lupine, potatoes, and oats was conducted in the 16 weeks following the time of sowing (planting) the crops in the field.
\end{abstract}

\section{Results and conclusions}

Such investigated temporal dynamics of water consumption has pointed to strong correlations of this consumption with radiation balance, saturation deficit, and bioclimatic coefficients of the agricultural crops. The new coefficients were proposed, providing more precision than the studies conducted previously in Russia, applied in the methods of calculating water consumption and vertical moisture exchange. There exists a need to calculate the optimum irrigation regime of drained soils, and to plan the regime for complex land reclamation, including technologically contaminated lands.

Keywords: soil moisture, heat cost, radiation balance, bioclimatic coefficients, ground water level

\section{INTRODUCTION}

The problem of soil, water and plants pollution, caused by man-induced stresses on catchments and landscapes, has intensified in recent decades in many regions of the planet. Pollutants accumulate in various components of the biosphere. They reduce the stability of terrestrial and aquatic ecosystems, affect the bioproductivity and quality of agricultural products, health and human well-being. In the irrigated area, the

凶e-mail: krystyna.brys@ugwr.edu.pl 
biohydrogeochemical system undergoes significant technogenic stresses, affecting all links of that system. In conditions of technogenic pollution, the role of complex amelioration of agricultural lands increases and becomes more complicated. The priority direction for the implementation of complex melioration is the creation of sustainable, environmentally safe reclaimed agro-landscapes and obtaining the environmentally friendly agricultural products. Among the most pressing problems is the scientific substantiation of land reclamation regimes that reduce the anthropogenic load on agricultural landscapes and aquatic ecosystems, coupled with the development of new environmentally friendly technologies. Irrigation itself influences the formation of the natural background of zonal soil of the automorphic series, transforming it into hydromorphic ones. This leads to a gradual deterioration in soil's water-physical properties and fertility loss. In this case, the loss of active humus is possible. Therefore, optimal two-way regulation of the water regime of irrigated soil is one of the key factors for maintaining its fertility.

The aim of the work is to develop methods for calculating water consumption of plants and vertical moisture exchange, while focusing on the influence of meteorological factors on the agricultural conditions of reclaimed soils. Therefore, this article considers the problem of reducing errors and improving the existing methods of calculating water consumption and vertical moisture exchange in the investigated environmental conditions of such soils with three selected agricultural crops. We propose to verify the research hypothesis that tested empirical methods for determining the vertical moisture exchange in soil, which take into account not only radiation balance and such meteorological characteristics as air temperature, air humidity or saturation deficit but also crops' biological characteristics and different water-physical properties of the soils render reliable results. Such methods could be used in calculations of the water regime in the design and exploitation of reclamation systems.

\section{MATERIAL AND METHODS}

The process of water consumption is determined by a various number of factors, which, in turn, also vary greatly. These are meteorological indicators, yield, crop properties and soil conditions (Hanks, 1992; Marshall et al., 1996; Monteith, 1964; Monteith and Unsworth, 1988; Roth, 2012; Walczak and Usowicz, 1994). The closest dependence of water consumption is noted with the radiation balance (Bryś, 1998, 2013; Kapuściński, 2000; Shebeko et al., 1965, 1980). At the same time, it has a close connection with all other meteorological factors (Bac and Kuchar, 2001; Bryś, 1998, 2002; Budagovskiy, 1964, 1981; Sidorov, 1985).

The methods of Shebeko (Shebeko et al., 1965, 1980), Rogotskiy (1981) and Pylenok (1985), which are commonly used in Russia, were assumed as the basis of the research. According to these methods and the empirical formulas, the calculations of vertical moisture exchange were made. The actual data from lysimetric studies with variable and constant water level in the period from the beginning of May to the end of September, which was not used in the derivation of the formulas, was adopted as control values. The empirical data of agro-climatologic, radiation, lysimetric and soil moisture measurements in the period from the beginning of May to the end of September during the years 1981-2018, was taken into account in the conducted analyses. The analysis of the influence of meteorological factors on the water balance was conducted in the 16 weeks following the time of field crops sowing (planting). Such 38-year analysis is of much longer duration than earlier, similar analyses, e.g Pylenok (1985), Shebeko et al. (1980). It should therefore facilitate obtaining new coefficients, with more precision than earlier works previously conducted in Russia (Shebeko et al., 1965, 1980; Rogotskiy, 1981; Pylenok, 1985) for the applied methods of calculating water consumption and vertical moisture exchange. The used empirical methods for determining the vertical moisture exchange have taken into account the crops' biological characteristics, the conditions for the heat and moisture availability of the calculation periods, the power and humidity of the soil layer under study, the water-physical properties of the ground, and the groundwater depth.

The studies were carried out on an ecological landfill - a large-scale natural model created in the "Oka" river basin, near Riazań (central part of the Russian Plain, about $200 \mathrm{~km}$ south-east of Moscow), used to conduct comprehensive land reclamation research and 
obtain information that is necessary to solve the problems of rational water use. The ecological landfill has an area of 3000 hectares and represents a landscape of the forest-steppe zone, typical for the Meshchera lowlands (Stelmah and Sidorov, 1982). The area has a humid continental climate (Kobysheva, 2001; Peel et al., 2007) with annual average air temperature of $5.4^{\circ} \mathrm{C}$ (minimum $-7.9^{\circ} \mathrm{C}$ in February) and average annual precipitation $621 \mathrm{~mm}$ (minimum $28 \mathrm{~mm}$ in March). During the warm period (May-September), the mean air temperature amounts to $15.8^{\circ} \mathrm{C}$ (with the maximum of $19.2^{\circ} \mathrm{C}$ in July), and average sum of precipitation is $314 \mathrm{~mm}$ (with the maximum of $88 \mathrm{~mm}$ in July). The annual average of relative air humidity amounts to $76 \%$ with winter maximum $85 \%$ in December and January, and spring minimum $61 \%$ in May. This humidity during warm months (May-September) steadily increases to $77 \%$ in September.

The methodological basis of the work is the application of systematic and expert-analytical approaches to the organization of soil-ecological survey of the agro-landscape, with intensive anthropogenic impact, the development of environmentally safe twoway regulation of the water regime by irrigation and drainage, counting on vertical moisture exchange in the soil. The soil surveys, laboratory, field experiments, analytical research and analyzes were carried out according to the Dospehov's methodology (Dospehov, 1985). Processing of research materials was carried out using the methods of mathematical data processing in land reclamation and soil science (Bishov and Kalmikov, 1977), analysis of variance, calculation of statistical characteristics of the sample, linear correlation (Ostapchik and Fillipenko, 1978). The closed type lysimeters of thick metal, with a diameter of 1.5 meters, and a depth of 2 meters were used. This is the soil of undisturbed addition, which atmospheric or irrigated moisture passes through (Pavlov, 2018). The actual data of lysimetric research with variable and constant water level, which was not used in the derivation of the formulas, was taken as control values.

The Authors propose a complex research approach, where not only the features of intra-day or week to week dynamics of water consumption and meteorological factors and results of correlation analysis between these factors and water consumption but also the water regime of soil and vertical moisture exchange in the aeration zone are taken into account. Such approach, springing from the wider, bioclimatic perspective as well as physical soil-water conditions, shows that the water consumption is connected both with the radiation balance and other meteorological factors, and demonstrates the impact of bioclimatic coefficients of this consumption on three research agricultural crops: lupine, potatoes, and oats.

\section{RESULTS AND DISCUSSION}

The process of water consumption is determined by numerous factors, which, in turn, also vary greatly (Allen et al., 1998; Monteith, 1964; Monteith and Unsworth, 1988; Shebeko et al. 1965, 1980; Stelmah and Sidorov, 1982). These are meteorological indicators, yield, crop properties and soil conditions (Marshall et al., 1996; Pielke, 1984; Roth, 2012; Shebeko et al., 1965, 1980; Sidorov, 1985; Stull, 1988). The close correlation of water consumption with the radiation balance is noted, and it also has a close correlation with other meteorological factors (Bac and Kuchar, 2001; Bryś, 1998, 2002, 2013; Bryś and Bryś, 2019; Budagovskiy, 1964, 1981; Kapuściński, 2000). In order to determine the meteorological factors that have the greatest impact on water consumption, we performed a correlation analysis of its weekly and separately-daily values with heat and moisture supply indicators. The closest correlation of water consumption were noted with total radiation, radiation balance, and saturation deficit $(r=0.64-0.85)$, significant correlation was observed with sunshine duration, air temperature, and air humidity $(\mathrm{r}=0.50-0.65)$, whereas less stable correlation was found with wind speed, evaporation from the water surface, precipitation, and soil temperature $(r=0.32-0.40)$. In certain periods, the correlation ratios increase by $5-7 \%$ and are significant at a probability of $0.95-0.99$.

To simplify the measurements and to obtain information more quickly, the correlations between water consumption and air temperature, and between water consumption and saturation deficit were studied at different hours of the day: noon, 3 p.m. and 6 p.m. in local summer time. The closest correlation was observed between daily water consumption and saturation deficit, measured at 3 p.m. (d15). It is an extreme value, 
which characterizes the evaporation conditions on the given day more accurately in comparison with the average daily deficit. In turn, the radiation balance is closely correlated with the saturation deficit, and then with the air temperature and air humidity.

Thus, it is established that the fluctuation of water consumption of crops occurs synchronously throughout the day, and the maxima of these factors coincide with the true noon, and they occur at $2-3$ p.m. in summer local time. Therefore, in the daily period, the correlation between water consumption and radiation is linear in the phases of crops' development. The transition of the radiation balance from negative to positive values takes place, on average, one hour after sunrise, and the reverse transition is observed in the evening, 1.5 hours before sunset.

The water consumption coincides with the beginning and the end of the sunlight exposure. However, the absence of a maximum intensity value in this indicator reduces the correlation and the possibility of applying it in calculating water consumption. The duration of sunshine is largely a factor determining the radiation balance and the deficit of air humidity.

During the day, the air temperature, relative humidity and saturation deficit in the dynamics have the same trends. The minimum values of air temperature and saturation deficit, as well as the maximum values of air humidity coincide with the minimum of solar radiation. However, their maximum values are late relative to the maximum of water consumption for 2-4 hours, with a significant decrease in water consumption during this period. Therefore, in the second half of the day, with a significant decrease in total evaporation, the values of these indicators can be quite significant. The established non-synchronicity in the oscillations of these quantities is the reason for the nonlinearity of the water consumption correlation with the temperature and humidity of the air.

The conducted experimental research, as well as statistical and correlation analyses demonstrate that in the calculations of water consumption, the radiation balance (Bryś, 2013; Bryś et al., 2018, 2020; Budagovskiy, 1964, 1981; Paszyński et al., 1999; Sidorov, 1985) or the deficit of air humidity (Budagovskiy, 1964, 1981; Bryś, 1998, 2002) can be used as meteorological factors. They count on the thermal energy presence for evaporation, are indicators of moisture availability, and have close correlation with water consumption and heat costs for evaporation (Allen et al., 1999; Bac and Kuchar, 2001; Bryś, 1998, 2013; Kapuściński, 2000; Monteith, 1964; Monteith and Unsworth, 1988). Added to that is the absorption and distribution of solar radiation and long-wave radiation by so called active surface (Geiger et al., 2003; Oke, 1995; Paszyński et al., 1999; Pielke, 1984; Stull, 1988). The radiation balance $(B)$ and the heat costs $(V)$, measured at the meteorological area of the experimental section, are associated with a moisture deficit of the air (saturation deficit) by curvilinear correlation, and with each other - by rectilinear correlation.

$$
V=0.70 B+0.01
$$

The correlation coefficient is 0.99 , which indicates a functional dependence. Uniform in biological development, natural grass cover on the meteorological site with periodic underfeeding shows relatively constant water consumption. Therefore, the variability of the thermal factor - the solar radiation - has a significant effect on its dynamics, and the biological factor has a constant value. This increases the tightness of the connection and determines its linear nature. However, when analyzing the tightness of the connection between water consumption of potatoes and the radiation balance, a close correlation can be traced only by periods of biological development.

The features of intra-day dynamics of water consumption and meteorological factors, coupled with correlation analysis, point to the existence of the water consumption's link with both the radiation balance and the saturation deficit. Therefore, to calculate the water consumption $(E)$, it is recommended that the following dependencies be applied:

$$
\begin{aligned}
& E=K_{B} \cdot B \cdot n \\
& E=K \cdot d_{S} \cdot n
\end{aligned}
$$

where:

$B \quad$ - radiation balance, $\mathrm{MJ} \cdot \mathrm{m}^{-2}$;

$d_{S} \quad$ - average daily saturation deficit, $\mathrm{hPa}$;

$K_{B}, K-$ bioclimatic coefficients of water consumption of agricultural crops (see: Table 1);

$n-$ duration of the calculation period, day. 
Mazhayskiy, Y.A., Bryś, K., Guseva, T. M., Pavlov, A. A. (2020). The impact of the meteorological factors on the calculation of crops water consumption and vertical... Acta Sci. Pol., Formatio Circumiectus, 19 (1), 3-12. DOI: http://dx.doi.org/10.15576/ASP.FC/2020.19.1.3

Table 1. Mean values of bioclimatic coefficients of the field crops' water consumption

\begin{tabular}{|c|c|c|c|c|c|c|c|c|c|}
\hline \multirow{2}{*}{ Culture } & \multirow{2}{*}{ Indicators } & \multicolumn{8}{|c|}{ Weeks from the time of field crops sowing (planting) } \\
\hline & & 1 & 2 & 3 & 4 & 5 & 6 & 7 & 8 \\
\hline \multirow{2}{*}{ Lupine } & $K_{B}$ & 0.10 & 0.15 & 0.19 & 0.27 & 0.27 & 0.28 & 0.47 & 0.34 \\
\hline & $\kappa$ & 0.19 & 0.25 & 0.35 & 0.45 & 0.54 & 0.57 & 0.92 & 1.01 \\
\hline \multirow{2}{*}{ Potatoes } & $K_{B}$ & 0.10 & 0.10 & 0.15 & 0.23 & 0.25 & 0.30 & 0.32 & 0.35 \\
\hline & $K$ & 0.15 & 0.17 & 0.27 & 0.31 & 0.53 & 0.53 & 0.68 & 1.42 \\
\hline \multirow{4}{*}{ Oats } & $K_{B}$ & 0.09 & 0.14 & 0.26 & 0.33 & 0.32 & 0.31 & 0.42 & 0.47 \\
\hline & $K$ & 0.17 & 0.20 & 0.18 & 0.56 & 0.65 & 0.61 & 0.86 & 1.38 \\
\hline & & \multicolumn{8}{|c|}{ Weeks from the time of field crops sowing (planting) } \\
\hline & & 9 & 10 & 11 & 12 & 13 & 14 & 15 & 16 \\
\hline \multirow{2}{*}{ Lupine } & $K_{B}$ & 0.33 & 0.25 & 0.28 & 0.20 & 0.16 & - & - & - \\
\hline & $K$ & 0.83 & 0.64 & 0.62 & 0.40 & 0.32 & - & - & - \\
\hline \multirow{2}{*}{ Potatoes } & $K_{B}$ & 0.27 & 0.31 & 0.35 & 0.30 & 0.26 & 0.22 & 0.28 & 0.11 \\
\hline & $K$ & 0.86 & 0.70 & 0.73 & 0.62 & 0.62 & 0.42 & 0.45 & 0.19 \\
\hline \multirow{2}{*}{ Oats } & $K_{B}$ & 0.32 & 0.31 & 0.36 & 0.20 & 0.24 & 0.29 & 0.15 & - \\
\hline & $K$ & 0.87 & 0.77 & 0.74 & 0.40 & 0.54 & 0.61 & 0.34 & - \\
\hline
\end{tabular}

The water regime of soil is largely formed under the influence of vertical moisture exchange in the aeration zone. It is usually determined by empirical formulas in the melioration regimes' calculations for local areas. In the conditions of the region under consideration, for sandy loam soil and loamy soil they are absent, therefore, a correlative analysis has been made on the basis of our research. The latter showed that during the vegetative period of plants, the correlation coefficient of the weekly values of total moisture exchange (taking into account basin recharge and infiltration) in the aeration zone is: with the $G W L$ (groundwater level) -0.44 ; moisture reserves at the beginning of the calculation period -0.53 ; air temperature -0.14 ; air humidity -0.27 ; saturation deficit -0.33 ; volatility according to Ivanov (1957) -0.23 ; water consumption -0.38 ; the sum of precipitation and watering -0.54 ; average daily water consumption for the calculation period -0.60 ; the ratio of the average daily deficit of water consumption to relative moisture reserves in the calculated soil layer, expressed in fractions of $L W C-$ 0.65. $L W C$ is an acronym for Least Water Capacity or extreme field water capacity. It is an amount of moisture, which could be intercepted from a soil after pro- fuse wetting from precipitation or irrigation when the gravitational water had flown out. Therefore, it is an amount of dampness which could be intercepted from a soil due to its the structure of capillary aggregates.

The correlations between vertical moisture exchange, deficit of water consumption $\Delta D$ and soil moisture are curvilinear. The correlation coefficients of the selected factors with vertical moisture exchange significantly increase for the periods of development of cultures. Thus, during the periods of "flowering" and "tubers formation" of potato, the correlations between vertical moisture exchange and water use deficit increases, and the correlation coefficient increases up to $r=0.86-0.92$. This is due to more accurate consideration within the individual development periods, biological features, water consumption and dynamics of root system growth. It was found that the correlations with different factors are not the same in case of separate consideration of the moisture exchange components, basin recharge and infiltration. The main determining factor for basin recharge is ground water level $(r=0.70-0.80)$, while for infiltration it is the water consumption deficit $(r=0.60-0.90)$. At the same time, deficit of water consumption $\Delta D$, horizon (depth 
in $\mathrm{m}$ ) of the ground water level $H$ and relative moisture of this soil layer $K_{w}$ have a direct impact on infiltration, direct impact on basin recharge and water demand deficit, and reverse effect on the soil moisture $K_{w}$ and groundwater level GWL. Consequently, an increase in basin recharge corresponds to an increase in the deficit of water consumption, a decrease in the moisture content of the root layer and the depth of groundwater.

The formula for the calculation of vertical moisture exchange $( \pm R)$ of field crops on drained soils with a close occurrence of horizon of the groundwater level $H$ is as follows [mm / day]:

$$
\pm R=a \cdot(\Delta D)^{b} \cdot\left(K_{w}\right)^{c} \cdot e^{d \cdot H} \cdot n
$$

where:

$$
\Delta D=(E-P-w)
$$

$\Delta D$ - deficit of water consumption, [mm/day];

$E$ - water consumption, [mm/day];

$P$ - precipitation for the calculation period, [mm/day];

$w$ - watering for the calculation period, [mm/day]

$K_{w}=W_{O} / W_{L W C}$ - relative moisture of the calculated soil layer, [\%];

$W_{O}, W_{L W C}-$ respectively, the actual soil moisture at the opening $(O)$ of the period and at the level of $L W C$, [\%].

$H \quad-$ horizon (depth from the soil surface) of the ground water level $(G W L),[\mathrm{m}]$;

e $\quad-$ is the base of the natural logarithm;

$$
\begin{array}{ll}
a, b, c, d- & \text { empirical coefficients (see: Table 2); } \\
n & - \text { duration of the calculation period, } \\
& \text { [day]; }
\end{array}
$$

Significant areas of the region under consideration have groundwater levels of more than 1.8-2.0 m. When irrigating these lands, vertical water exchange should also be taken into account. The conditions of its formation differ from moisture exchange in case of shallow groundwater. Taking into account the depth of the root system of the studied plants (Stankov, 1964), the height of the capillary rise for sandy loam soil, and the detailed study of the moisture content of the soil profile (Stelmah and Sidorov, 1982), it is established that appreciable groundwater basin recharge of the root system of lupine is possible from the depth of $1.7 \mathrm{~m}$, of potatoes $-1.5 \mathrm{~m}$, and of oats $-1.6 \mathrm{~m}$. For the noted depths of groundwater, formulas are obtained for calculating the vertical moisture exchange of the calculated soil layer with the underlying layers, as follows:

$$
\pm R=a 1 \cdot(\Delta D)^{b 1} \cdot\left(K_{w}\right)^{c 1} \cdot n
$$

where:

$$
a 1=a \cdot e^{d \cdot H}
$$

$a, a 1, b 1, c 1, d-$ empirical coefficients (see: Ta-

\begin{tabular}{|c|c|c|c|c|c|c|c|c|}
\hline \multirow{3}{*}{ Culture } & \multirow{3}{*}{$\Delta D$} & \multicolumn{7}{|c|}{ Sandy loam soil } \\
\hline & & \multicolumn{4}{|c|}{ Drained $H<1.5-1.7 \mathrm{~m}$} & \multicolumn{3}{|c|}{$H \geq 1.5-1.7 \mathrm{~m}$} \\
\hline & & $a$ & $b$ & $c$ & $d$ & $a 1$ & $b 1$ & $c 1$ \\
\hline \multirow{2}{*}{ Lupin } & $>0$ & 33.70 & 0.70 & -1.95 & -4.20 & 0.027 & 0.70 & -1.95 \\
\hline & $<0$ & 0.32 & 0.34 & 1.92 & 0.10 & 0.379 & 0.34 & 1.92 \\
\hline \multirow{2}{*}{ Potatoes } & $>0$ & 285.4 & 0.28 & -3.92 & -5.80 & 0.048 & 0.28 & -3.92 \\
\hline & $<0$ & 0.32 & 0.34 & 1.92 & 0.10 & 0.372 & 0.34 & 1.92 \\
\hline \multirow{2}{*}{ Oates } & $>0$ & 48.6 & 0.73 & -2.79 & -3.50 & 0.180 & 0.73 & -2.79 \\
\hline & $<0$ & 0.32 & 0.34 & 1.92 & 0.10 & 0.376 & 0.34 & 1.92 \\
\hline
\end{tabular}
ble 2).

$R, \Delta D, K_{w}, n \quad-$ as in formula (4)

The total correlation coefficient for the empirical dependence (7) is $0.68-0.90$ and is reliably at a probability of $0.95,0.99$. The obtained dependences can

Table 2. Empirical coefficients for vertical moisture exchange calculation 
be applied to water balance calculations of the water regime of meliorated lands with deep groundwater occurrence. They are applicable at relative humidity of soil $\left(K_{w}\right)=0.5-2.0$.

On the drained sandy loam soil of the region, it is recommended that formula (4) be applied for vertical moisture exchange calculation. It is recommended that dependence (7) be used at a groundwater level $H>1.5$ m under potatoes, oats and lupines $H>1.6-$ $1.7 \mathrm{~m}$. At $H<0.5 \mathrm{~m}$, the vertical moisture exchange of the calculated soil layer should be assumed to be equal to the deficit of water consumption with the opposite sign. The coefficients of regression in the empirical dependence (4) for calculating the positive component of moisture exchange - basin recharge the root layer of the soil under potatoes - differ significantly from the coefficients calculated using formula (7) for lupine and oats. The biological features of the crops and the depth of the root system development significantly impact their values for sandy-loam soil. The regression coefficients for determining the negative component of vertical moisture exchange differ less significantly, as the moisture infiltration beyond the calculated layer of soil is basically a physical process.

The coefficient takes the values of $a=5.52, b=0.41$, $c=-4.24$, and $d=-1.91$ in calculations of vertical moisture exchange using formula (4) for loamy soil for $\Delta D>0$, and, respectively, $0.48,0.37,4.28,-0.20$ for $\Delta D<0$, taking into account a significant number of fine particles in the composition of loamy soil, compared with sandy loam soil, which regulate the moisture retention and movement; these do not significantly change for the field crops under consideration.

The coefficients of regression of empirical equations point at the peculiarities of the influence of constituent factors in regard to vertical moisture exchange. The $d$ coefficient characterizes the ability of the crop to use the groundwater moisture through the root system, taking into account the soil type. The $c$ coefficient takes into account the impact of the soil water-physical properties and the moisture of the calculated layer on the moisture exchange value. The 8 coefficient is determined by the biological characteristics of water consumption and meteorological conditions (the amount of thermal energy, precipitation and so on). The coefficients $a$ and $d$ take into account the biological characteristics of the moisture consumption from soil by plants. Ultimately, the calculated value of vertical moisture exchange is determined taking into account the compounded influence of complex natural and biological factors.

As follows from the formula (4), the vertical moisture exchange depends on the deficit of water consumption $(\Delta D)$. In turn, the water consumption as a function of yield and air moisture deficit depends on the level of soil pollution with heavy metals and microelements. This is expressed in biological coefficients, using formula (3). Correlation analysis shows that the vertical moisture exchange is a significant factor in the water balance of sandy loam soil. Its value is equal to one or even several watering events at $75 \%$ moisture supply. With an increase in the yield of field crops, the vertical moisture exchange and basin recharge increase, and the infiltration naturally decreases. These changes are almost stabilized in case of the maximum yield. Across the whole studied territory, the basin recharge, and, consequently, the total moisture exchange increase insignificantly from the north to the south of the Oka river basin. The groundwater levels in the calculations of the drained land according to the developed algorithm were varied dynamically (depending on the moisture content of the year) from 0.7 to $1.8 \mathrm{~m}$.

In the soil with deep groundwater occurrence, the immediate basin recharge of the aeration zone is absent. The positive moisture exchange at the boundary of the calculated soil layer is determined by the moisture volume redistributed between the soil layers, and is an insignificant quantity. The oat uses the moisture of the underlying soil layers more fully. There is a significant moisture infiltration from the calculated soil layer into the underlying horizons on lands with deep groundwater occurrence, therefore the total vertical moisture exchange is mostly negative. The values of vertical moisture exchange can be used in calculations of the soil water regime, in determining the value of irrigation norms, and in estimating the share of basin recharge in water consumption of plants.

The methods of Shebeko (Shebeko et al., 1965), Rogotsky (1981) and Pylenok (1985) can be applied, taking into account the initial data, for the calculations of vertical moisture exchange on the sandy-loam soil of the studied region. According to these methods and empirical formulas $(4,7)$, the calculations of vertical moisture exchange are made. The control values were 
taken from the actual data of lysimetric studies with variable and constant water level, which were not used in the derivation of the formulas.

The results of the comparison show that the recommended method in this work produces smaller errors in determining the vertical moisture exchange. The deviations of the calculated values from the actual ones vary from +5 to $-12 \%$. The maximum deviations were obtained in calculations based on the methods of Rogotsky and Pylenok. This is explained by the insufficient consideration of the soil type and the biological properties of the potato in the empirical formulas proposed by the aforementioned authors.

\section{CONCLUSIONS}

It is absolutely necessary to obtain water consumption values of agricultural crops and vertical moisture exchange in the soil in the regimes of water balance of agricultural reclaimed lands. These values can be acquired only by way of experimental studies or as a result of calculations based on empirical correlations. As a result of field research in situ, the methods for calculating water consumption and vertical moisture exchange are developed and proposed for application.

It is recommended that the values of the water consumption of irrigated crops (in the operational regime of irrigation, in the calculation of the water balance) should be determined according to: the indicators of heat supply of the area, that is, the radiation balance; air humidity deficit and bioclimatic factors of water consumption, taking into account the type and phase of plants development, the physical condition and soil moisture content.

The empirical method for determining the vertical moisture exchange takes into account the biological characteristics of crops, the conditions for the heat and moisture availability of the calculation periods, the soil water potential and humidity of the soil layer studied, the water-physical properties of the ground, and the depth of the groundwater. It renders reliable results and can be used in calculations of the water regime, in designing and exploitation the reclamation systems.

Groundwater affects the formation of the soil water regime in the aeration zone. At shallow occurrence, it increases the humidity in the root layer, which makes it possible to reduce the irrigation rates and the num- ber of irrigation events. This circumstance needs to be taken into account in calculating the optimal irrigation regime of the drained soil, i.e. with bilateral regulation of humidity in the root zone of the soil, and in general planning for regimes of complex land reclamation including technologically contaminated lands.

\section{REFERENCES}

Allen, R.G., Pereira, L.S., Raes, D., Smith, M. (1998). Crop Evapotranspiration: Guidelines for Computing Crop Requirements, Irrig. Drain. Pap. 56, Food and Agric. Organ. of the U.N., Rome.

Bac, S., Kuchar, L. (2001). Estimation of potential evaporation by modified Turc formula. Ann. UMCS, Sectio $\mathrm{B}$, Geographia, geologia, Mineralogia et Petrographia, 55/56, 41-49 (in Polish).

Bishov, I, Kalmikov, G.S. (1977). Methodological guidelines for the statistical processing of experimental data in land reclamation and soil science, Moscow. (in Russian).

Bryś, K. (1998). The role of radiation factor in evapotranspiration. Zesz. Nauk AR Wrocław, Inż. Środowiska X, 349, 17-51 (in Polish).

Bryś, K. (2002). The new wroclavian formula on potential evaporation. Rocz. AR Poznań, Melioracje, 338, 22, 21-30 (in Polish).

Bryś, K. (2013) Dynamics of net radiation balance of grass surface and bare soil. Monografie CLXII. Wrocław: Wyd. UP we Wrocławiu. (in Polish).

Bryś, K., Bryś, T. (2019). Multi-annual variability of global solar radiation in the agricultural area of Lower Silesia (SW Poland) and its relationship with the North Atlantic Oscillation. Meteorology Hydrology and Water Management. Research and Operational 7, 13-25. doi. org $/ 10.26491 / \mathrm{mhwm} / 103461$

Bryś, K. Bryś, T., Sayegh, M. A., Ojrzyńska, H. (2018). Subsurface shallow depth soil layers thermal potential for ground heat pumps in Poland. Energy and Buildings, 165, 64-75. doi.org/10.1016/j.enbuild.2018.01.015

Bryś, K. Bryś, T, Sayegh, M. A., Ojrzyńska, H. (2020). Characteristics of heat fluxes in subsurface shallow depth soil layer as a renewable thermal source for ground coupled heat pumps. Renewable Energy, 146, 1846-1866. doi. org/10.1016/j.renene.2019.07.101

Budagovskii, M.I. (1964) The soil moisture evaporation. Science, Moscow (in Russian).

Budagovskii, A. I. (1981) The scientific research of assessments of irrigation needs and irrigation systems calculation. Modern problems of hydrology of irrigated lands. Moscow, 16-32. (in Russian). 
Dospehov, B.A. (1985) The field experience methodology, Agropromizdat. Moscow, 351. (in Russian).

Geiger, R., Aron, R. H., Todhunter, P. (2003). The climate near the ground. Oxford: Rowman \& Littlefield Publish.

Hanks, R. J. (1992). Applied Soil Physics: Soil Water and Temperature Applications. New York: Springer-Verlag.

Ivanov, N.N. (1957) The world map of evaporativity. Leningrad: Gidrometeoizdat. (in Russian).

Kapuściński, J. (2000). Heat balance structure of active surface on the background of climatic conditions of the west-middle Poland. Rocz. AR Poznań, Rozprawy Nauk. 303, Poznań (in Polish)

Kobysheva, N. V. (2001). The climate of Russia. St. Petersburg: Gidrometeoizdat (in Rusian)

Marshall, T. J., Holmes, J. W., Rose, C. W. (1996) Soil physics. Cambridge University Press.

Monteith, J.L. (1964). Evaporation and environment. The state and movement of water in living organisms, Symp. Soc. Exp. Biol., 19, 205.

Monteith, J.L., Unsworth, M. H. (1988). Principles of Environmental Physics. London: Edward Arnold.

Oke, T.R. (1995) Boundary layer climates. London: Methuen.

Ostapchik, V.P., Fillipenko, L.A. (1978). Methodological guidelines for conducting experimental researches and the calculation of bioclimatic coefficients of crop water consumption. Kiev (in Russian).

Paszyński, J., Miara, K., Skoczek, J. (1999). Exchange of energy between atmosphere and ground surface as a base of topoclimatic mapping. Warszawa: IGiPZ PAN, Dok. Geogr., 14, (in Polish).

Pavlov, A.A. (2018). Lizimetr. Patent RF, 2641193, (in Russian).

Peel, M.C., Finlayson, B.L., McMahon, T.A. (2007). Updated world map of the Koppen-Geiger climate classifications. Hydrol. Earth Syst. Sci., 11, 1633-1644, Doi:10.5194/hess-11-1633-2007

Pielke, R. A. (1984). Mezoscale meteorological modeling, Academic Press.
Pylenok, P.I. (1985) Changes in the soil water regime and water protection measures in the zone of the drainage systems impact. Diss. Cand. tech. Sc., Moscow, (publish. or manuscript in all grown. scientific.-research. Institute of hydraulic engineering and land reclamation them. A. N. Kostyakova.)(in Russian)

Rogotsky, V.V. (1981). The usage of lysimetric information for assessing the moisture exchange in the aeration zone. Water balance researches on reclaimed lands. Leningrad: Gidrometeoizdat, 128-139 (in Russian).

Roth, K. (2012). Soil Physics, Institute of Environmental Physics, Heidelberg University. www.iup.uni-heidelberg.de/institut/forschung/groups/ts/soil_physics/.../ sp-v2.2.pdf

Shebeko, V.F., Mozhzha, I.I., Kiseleva, A.I. (1965). The instructions and programs for computers in designing the water regime of drained lands on the basis of regime water balance calculations. Minsk: BelNIIMiVH (in Russian).

Shebeko, V.F., Zakrezhevsky P.I., Bragilevskaya E. A. (1980). The hydrological calculations in the design of drainage and drainage-humidifying systems. Leningrad: Gidrometeoizdat. (in Russian).

Sidorov, I. V. (1985). The water balance and the regime of moistening of the drained floodplain lands, Moscow, (publish. or manuscript in all grown. scientific.-research. Institute of hydraulic engineering and land reclamation them. A. N. Kostyakova.). (in Russian).

Stankov, I.Z. (1964) The root system of field crops. Moscow. (in Russian).

Stelmah, E.A., Sidorov, I.V (1982). The estimated method of forming the operating mode of irrigation of agricultural crops on the floodplain lands. Ryazan (in Russian).

Stull, R. B. (1988). An introduction to boundary layer meteorology, Kluwer Acad. Publish..

Walczak, R., Usowicz, B. (1994). Variability of moisture, temperature and thermal properties in bare soil and in crop field, Int. Agrophys. 8, 161-168.

\section{WPŁYW CZYNNIKÓW NATURALNYCH NA OBLICZANIE ZUŻYCIA WODY PRZEZ ROŚLINY UPRAWNE ORAZ PIONOWĄ WYMIANĘ WILGOCI W GLEBIE}

\section{ABSTRAKT}

\section{Cel pracy}

Celem pracy było doskonalenie metod obliczania konsumpcji wody przez rośliny oraz pionowej wymiany wilgoci w glebie, brano pod uwagę wpływ czynników meteorologicznych w agrokulturowych warunkach zrekultywowanych gleb. 


\section{Materiat i metody}

Jako podstawę badań przyjęto powszechnie stosowane w Rosji metody Shebeko, Rogotskiya i Pylenoka. Badania przeprowadzono na ekologicznym składowisku odpadów w zlewni rzeki Oka, koło Riazania (centralna część Równiny Rosyjskiej). Do analiz wykorzystano dane empiryczne z pomiarów agroklimatycznych, radiacyjnych, lizymetrycznych i wilgotności gleby wykonanych od początku maja do końca września w latach 1961-2018. W przeprowadzonych analizach wykorzystano takie metody jak analiza wariancji, obliczanie statystycznych charakterystyk próbki badawczej i korelację liniową. Przedstawiono analizę wpływu czynników meteorologicznych na bilans wodny gleby z trzema uprawami rolniczymi: łubin, ziemniaki, owies dla kolejnych 16 tygodni od czasu siewu (sadzenia) tych upraw.

\section{Wyniki i wnioski}

Tak badana dynamika czasowa konsumpcji wody wskazała na silne związki korelacyjne tej konsumpcji z bilansem radiacyjnym, niedosytem wilgotności powietrza oraz z bioklimatycznymi współczynnikami badanych upraw. Zaproponowano nowe, dokładniejsze niż dotychczas wyprowadzone w Rosji współczynniki dla wykorzystanych metod obliczania konsumpcji wody i pionowej wymiany wilgoci. Potrzebne są do uzyskania optymalnego reżimu irygacyjnego dla drenowanych gleb i w planowaniu tego reżimu dla kompleksowych systemów rekultywacji, w tym terenów skażonych technologicznie.

Słowa kluczowe: wilgotność gleby, koszt cieplny, bilans radiacyjny, współczynniki bioklimatyczne, poziom wody gruntowej 